\title{
Marketing of Crop Residues in Niamey city:
} Socio-organizational Aspects.

\author{
A.A. Maman Lawal ${ }^{* 12}$, M. Chaibou ${ }^{2}$, I. Hamadou ${ }^{1}$, A.S. Gouro ${ }^{2}$ \\ ${ }^{1}$ Département des Productions Animales, Institut National de la Recherche Agronomique du Niger, BP 429, Niamey-Niger. \\ ${ }^{2}$ Faculté d'Agronomie, Université Abdou Moumouni de Niamey, BP 10960, Niamey-Niger. \\ * Correspondence to be sent to: MAMAN LAW AL Abdoul Aziz, Département des Productions Animales, Institut National \\ de la Recherche Agronomique du Niger, Niamey, Niger. Phone number: +227 96992440. \\ Email address: malawa80@gmail.com
}

\begin{abstract}
A sample of 93 stakeholders was surveyed and monitored to analyze the socio-economic and organizational aspects of the marketing of crop residues used in animal feed in the city of Niamey. It emerges from this study that almost all the actors are male. More than $45 \%$ of actors are between 40 and 60 years old. The Hausa ethnic group is the majority of wholesalers / semiwholesalers (54.5\%). Those of the Zarma ethnic group are more numerous at the level of sellers / resellers $(92.7 \%)$, while those of the Fulani ethnic group represent the majority of street vendors $(57.9 \%)$. Inheritance and profitability were the main reasons that led to the activity of wholesalers/ semi-wholesalers (30.3\% and 24.2\%) and street vendors (26.3\% and 31\%). 6\%). Among sellers / resellers, it is rather survival $(24.4 \%)$, passion (22\%) and constraint (22\%). Most wholesalers / semi-wholesalers (60.6\%) and sellers / resellers (68.3\%) are supplied and delivered locally at their own point of sale. cash settlement is the most common (79\% for wholesalers / semi-wholesalers, $61 \%$ for sellers / resellers and $74 \%$ for street vendors). The daily gross margin of a wholesaler / semi-wholesaler of crop residues is $14753.03 \pm$ 25724.24FCFA. It is higher than that of street vendors (6946.05 \pm 2204.23 FCFA), which is also higher than that of sellers/resellers (5855.54 $\pm 5065.49 F C F A)$. In short, the marketing of crop residues is a very profitable activity for the actors, especially in the cold dry season. However, the recurrent displacements of actors for lack of fixed places and the harassment of the collection agents from the municipalities represent a brake on the development of this activity. It is therefore imperative to regulate their implementation while facilitating administrative procedures leading to the granting of authorization for installation.
\end{abstract}

Keywords-Cultivated residues, breeding, sale, Niamey, Niger.

\section{INTRODUCTION}

Livestock farming in tropical countries occupies a very important place in household activities (Zoffoun et al., 2013). It is a source of considerable income for the population and plays an important socio-cultural role (Steinfeld et al., 2010). In Niger, drought cycles have led in recent years, the descent of farmers in agricultural areas and their establishment almost permanently. This has resulted in a change in dietary practices, including the switch from extensive livestock farming using large areas to a semi-intensive or intensive system in urban centers (Faye and Alary, 2001). In addition, the low forage productivity despite the large area of primary pasture production $\left(620000 \mathrm{~km}^{2}\right)$, makes animal feed one of the main constraints of livestock farming in Niger (Chaibou et al., 2012; Rhissa, 2010; Maidadji, 2003). In order to alleviate this dietary constraint of booming urban and peri-urban farms, fodder food markets have developed (Sanou et al., 2011), in which speculation has taken place with several types of actors around crop residues. Thus, the marketing of crop residues is a profitable economic activity that is essential for the prosperity of urban and peri-urban livestock farming in Niamey. The objective of this study is to analyze the socio-economic and organizational aspects of the marketing of crop residues in the city of Niamey.

\section{MATERIALS AND METHODS}

\subsection{Study areas}

The study was conducted in the urban area corresponding to the large metropolitan area of Niamey which is subdivided into five communes (Niger, 2016). It is located in the western part of the country, between $2^{\circ} 10$ 'and $2^{\circ} 14^{\prime}$ east longitude and $13^{\circ} 33$ 'and $13^{\circ} 36^{\prime}$ north latitude (Beidari 1999, Niger 2015a). It covers an area of about 55227 ha with a tropical climate of the SudanoSahelian type characterized by an average temperature of $30.25^{\circ} \mathrm{C}$; a high of $42.1^{\circ} \mathrm{C}$ in April and a low of $17.8^{\circ}$ $\mathrm{C}$ in December. The average rainfall is $563.3 \mathrm{~mm} /$ year (Niger, 2015a). The vegetation is generally shrubby, sparse with seasonal-season herbaceous plants. Agriculture is practiced in a traditional way and occupies a good part of the population. Livestock occupies a prominent place in the activity of the population, and the herd is 105,212 TLU in 2015 (Niger, 2015b). 


\subsection{Data collection}

It was identified in the first months by an identification of the actors involved in the marketing of crop residues.

These actors are generally settled around livestock markets and on the main boulevards of the city of Niamey.

Thus, 296 actors identified during the period from November to December 2016 served as sampling frame. Then, 1/4 of the 296 identified actors, or 93 actors were randomly drawn. Among these 93 actors, there are 33 wholesalers / semi-wholesalers and 41 sellers / resellers. To these 93 actors drawn at random, 19 street vendors met during the same phase of identification were added. This gave a sample of 122 actors. The latter were selected for seasonal monitoring to see the effect on the activity. These include the hot dry season (March-June, 2017), the rainy season (July-October, 2017) and the cold dry season (November 2017-February2018). The information sought focused on the socio-economic characteristics of the actors, the different types of crop residues sold, the types of packaging, the price and weight of the local unit, and the stock available.

\subsection{Statistical analysis}

The collected data were coded and entered into a model built on the SPSS version 19 software. A descriptive statistic (Khi2 test, Fisher's exact test at the 5\% threshold) and an ANOVA (multivariate analysis, followed by the Levene error variances test) through the general linear model were performed between the variables. The averages were compared according to Duncan's test at the 5\% threshold. Some data has been exported to the Excel spreadsheet for the production of tables and figures.

\section{RESULTS}

\subsection{Socio-economic characteristics of actors}

The majority of the actors surveyed (more than $45 \%$ ) are relatively old (age between 40 and 60 years old). This study also shows a very low proportion of female actors (6.1\% wholesalers / wholesalers and $2.4 \%$ sellers / resellers), and a large proportion of single actors (52.6\%). at street vendors. We notice more actors of Hausa ethnic group at the level of wholesalers / semi-wholesalers; actors of ethnic Zarma at the level of sellers / resellers and actors of Fulani ethnicity at the level of street vendors. Also, the actors do not have much experience (less than 5 years) in the activity of selling fodder $(51.5 \%$ wholesalers / wholesalers, $34.1 \%$ sellers /resellers and $63.2 \%$ street vendors) and their majority activity is the sale of livestock feed $(60.6 \%)$ for wholesalers / semi-wholesalers; agriculture $(53.7 \%)$ for sellers / resellers and the sale of fodder $(68.4 \%)$ for street vendors (Table 1 ).

Table.1: Socio-economic characteristics of the respondents

\begin{tabular}{|c|c|c|c|c|c|c|c|c|}
\hline \multirow{2}{*}{ Variable } & \multirow{2}{*}{ Modality } & \multicolumn{2}{|c|}{ Wholesaler/ semi wholesaler } & \multicolumn{2}{|c|}{ Seller/ reseller } & \multicolumn{2}{|c|}{ Street vendor } & \multirow{2}{*}{$\mathrm{P}$ value } \\
\hline & & $\mathrm{N}$ & $\%$ & $\mathrm{~N}$ & $\%$ & $\mathrm{~N}$ & $\%$ & \\
\hline \multirow{4}{*}{ Age } & $>20 \leq 40$ years & 13 & 39.4 & 4 & 9.8 & 6 & 31.6 & \multirow{4}{*}{$*$} \\
\hline & $>40 \leq 60$ years & 15 & 45.5 & 9 & 63.4 & 50 & 47.4 & \\
\hline & $>60$ years & 5 & 15.2 & 11 & 26.8 & 4 & 21.1 & \\
\hline & Total & 33 & 100 & 41 & 100 & 19 & 100 & \\
\hline \multirow{3}{*}{ Sex } & Male & 31 & 93.9 & 40 & 97.6 & 19 & 100 & \multirow{3}{*}{ Ns } \\
\hline & Female & 2 & 6.1 & 1 & 2.4 & 0 & 0 & \\
\hline & Total & 33 & 100 & 41 & 100 & 19 & 100 & \\
\hline \multirow{4}{*}{ Marital status } & Married & 31 & 93.9 & 39 & 95.1 & 10 & 52.6 & \multirow{4}{*}{$* * *$} \\
\hline & Single & 2 & 6.1 & 1 & 2.4 & 9 & 47.4 & \\
\hline & Widower/widow & 0 & 0 & 1 & 2.4 & 0 & 0 & \\
\hline & Total & 33 & 100 & 43 & 100 & 19 & 100 & \\
\hline \multirow{5}{*}{ Ethnic group } & Haussa & 18 & 54.5 & 3 & 7.3 & 0 & 0 & \multirow{5}{*}{$* * *$} \\
\hline & Zarma & 11 & 33.3 & 38 & 92.7 & 8 & 42.1 & \\
\hline & Fulani & 2 & 6.1 & 0 & 0 & 11 & 57.9 & \\
\hline & Kanuri & 2 & 6.1 & 0 & 0 & 0 & 0 & \\
\hline & Total & 33 & 100 & 41 & 100 & 19 & 100 & \\
\hline \multirow{5}{*}{ Core business } & Agriculture & 12 & 36.4 & 22 & 53.7 & 6 & 31.6 & \multirow{5}{*}{$* * *$} \\
\hline & Fodder sale & 0 & 0 & 5 & 12.2 & 13 & 68.4 & \\
\hline & Sale of livestock feed & 20 & 60.6 & 12 & 29.3 & 0 & 0 & \\
\hline & Sale wood + Secko & 1 & 3 & 2 & 4.9 & 0 & 0 & \\
\hline & Total & 33 & 100 & 41 & 100 & 19 & 100 & \\
\hline \multirow{3}{*}{$\begin{array}{l}\text { Number of year } \\
\text { of exercise }\end{array}$} & $\leq 5$ years & 17 & 51.5 & 14 & 34.1 & 12 & 63.2 & \multirow{3}{*}{ Ns } \\
\hline & $>5 \leq 10$ years & 6 & 18.2 & 9 & 22 & 6 & 31.6 & \\
\hline & $>10 \leq 15$ years & 1 & 3 & 3 & 7.3 & 1 & 5.3 & \\
\hline
\end{tabular}




\begin{tabular}{lcccccc}
\hline$>15 \leq 20$ years & 4 & 12.1 & 5 & 12.2 & 0 & 0 \\
$>20$ years & 5 & 15.2 & 10 & 24.4 & 0 & 0 \\
Total & 33 & 100 & 41 & 100 & 19 & 100 \\
\hline
\end{tabular}

Ns $=$ not significant $; *=\mathrm{p}<0.05 ; * * *=\mathrm{p}<0.001 ; \mathrm{N}=$ effective $\% \%=$ Percent

3.2. Reasons for the practice of the commercialization of crop residues

The main reasons that led to the marketing practice of crop residues are among other reasons, inheritance and profitability respectively for wholesalers / semi- wholesalers $(30.3 \%$ and $24.2 \%)$ and street vendors ( $26.3 \%$ and $31.6 \%$ ). As for sellers / resellers, it is rather survival $(24.4 \%)$, passion $(22 \%)$ and constraint $(22 \%)$ (Figure1).

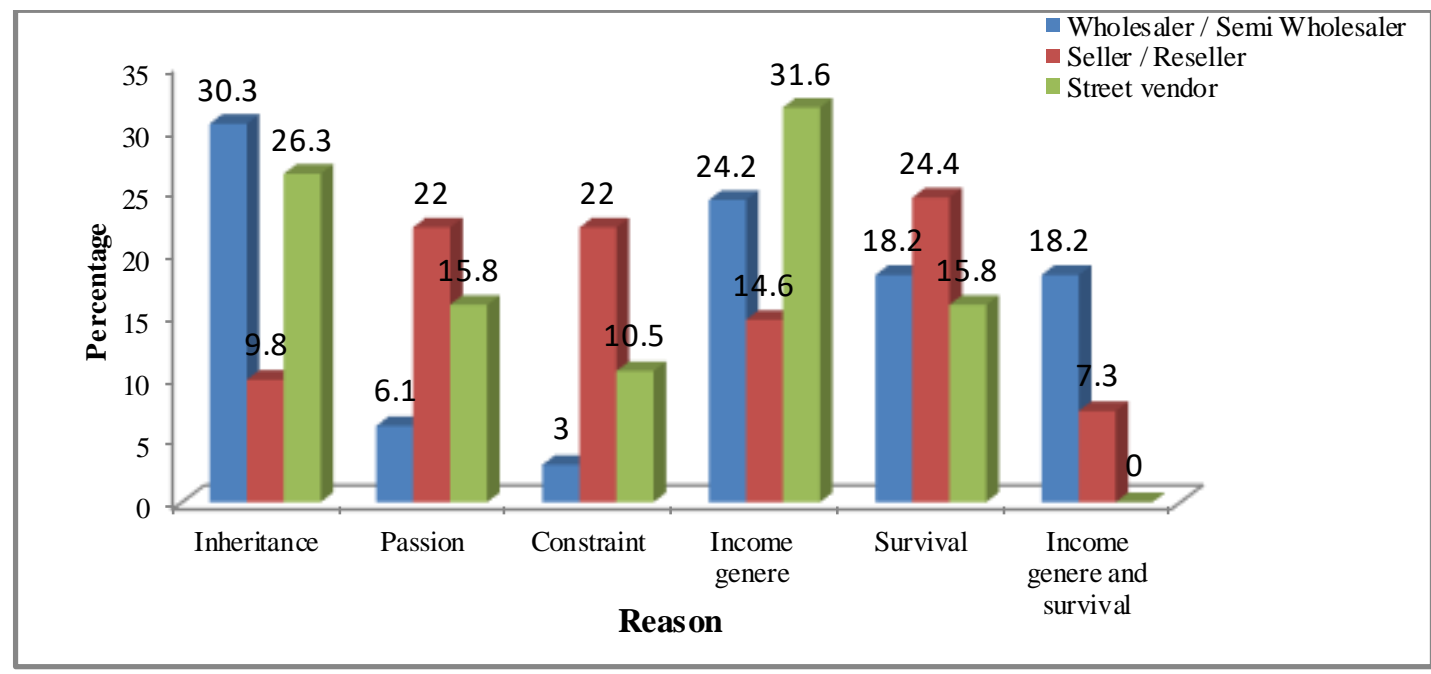

Fig. 1: Reasons for the practice of marketing crop residues

\subsection{Trade Organization}

\subsubsection{Type of crop residues sold}

The different types of crop residues encountered in the marketing system as livestock feed are cowpea haulm, groundnut haulm and rice straw. These last are object of specific sale, or of combined sale at the level of the various actors. Figure 2 shows that all street vendors surveyed sell cowpea haulm and $36.84 \%$ of them sell extra rice straw. Wholesalers / semi-wholesalers mainly combine cowpea and groundnuts haulm (57.6\%). The largest proportion of sellers / resellers sells specifically cowpea haulm $(43.9 \%)$, followed by the sale of cowpea haulm to groundnut haulm $(31.7 \%)$.

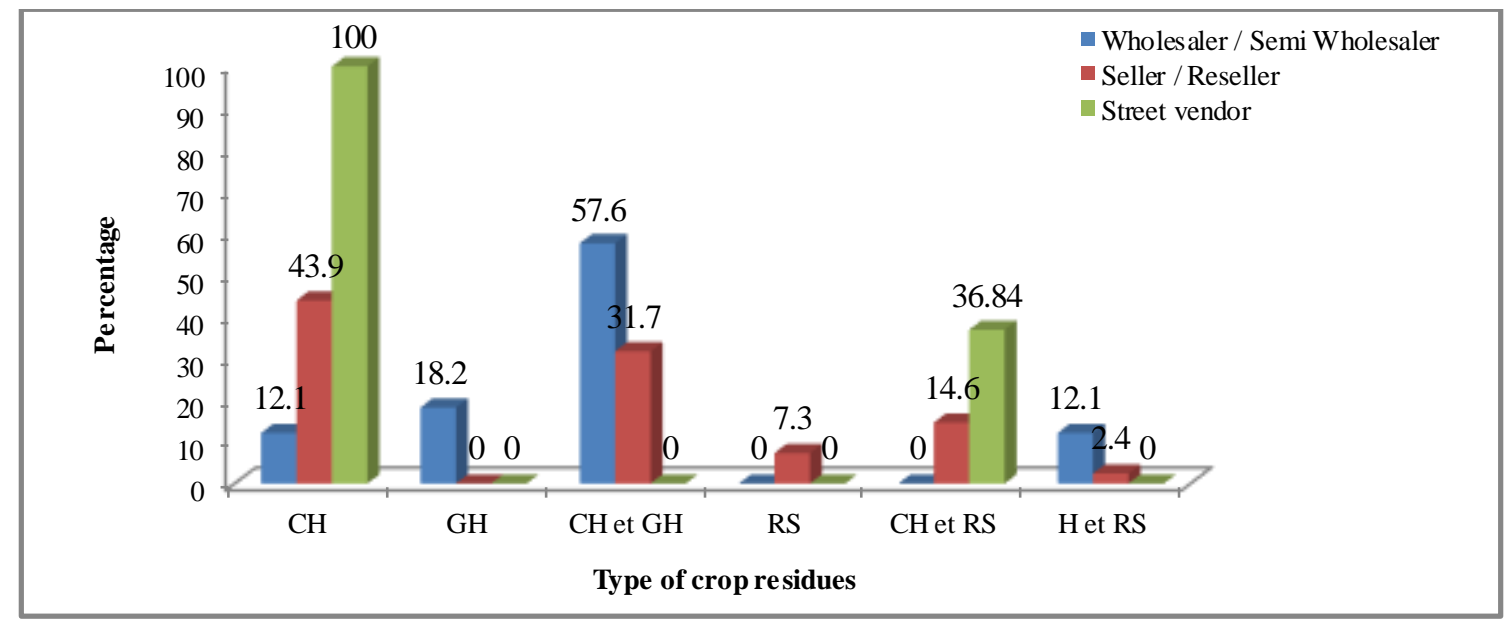

Fig. 2: The different types of crop residues sold

\subsubsection{Supply and delivery}

All street vendors obtain supplies from the producers. Most wholesalers / semi-wholesalers $(60.6 \%)$ and sellers / resellers $(68.3 \%)$ are supplied and delivered locally at their own point of sale (Figure 3). 


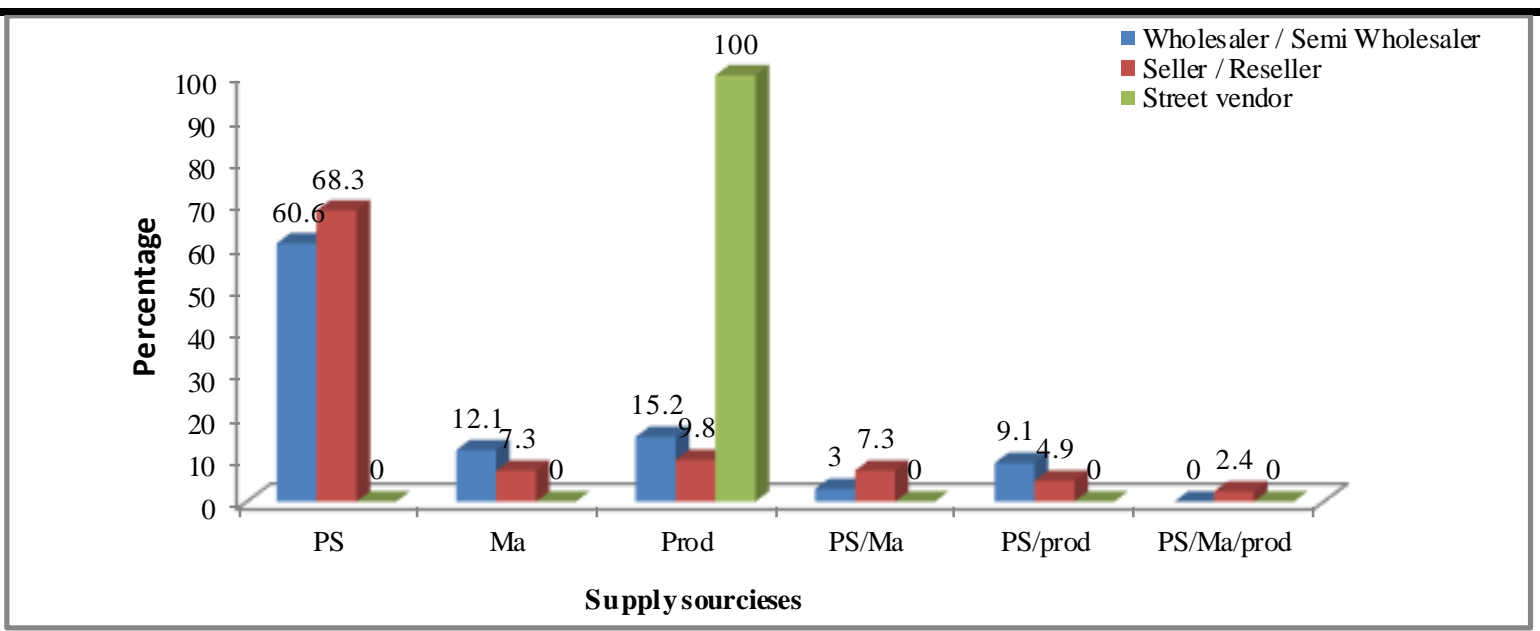

Fig. 3: Supply and delivery

\subsubsection{Quantity of crop residues per supply}

Street vendors stock up on boot of cowpea and rice straw. The quantities per supply are mainly between 50 and 100 boots of cowpea haulm (78.9\%) and 100 and 200 boots of rice straw (100\%). Wholesalers / semi-wholesalers supply mainly groundnut and rice straw. The quantity per supply is generally greater than 100 boots of groundnut haulm
(41.4\%) and more than 200 boots of rice straw $(66.66 \%)$. The vast majority of sellers / resellers are delivered relatively small quantities. A proportion of $57.1 \%$ is delivered 10 to 25 boots of groundnut haulms; $41.5 \%$ are fed a quantity of cowpea grass less than 25 boots and $49.68 \%$ are supplied with a quantity of rice straw of between 100 and 200 boots (Figure 4).

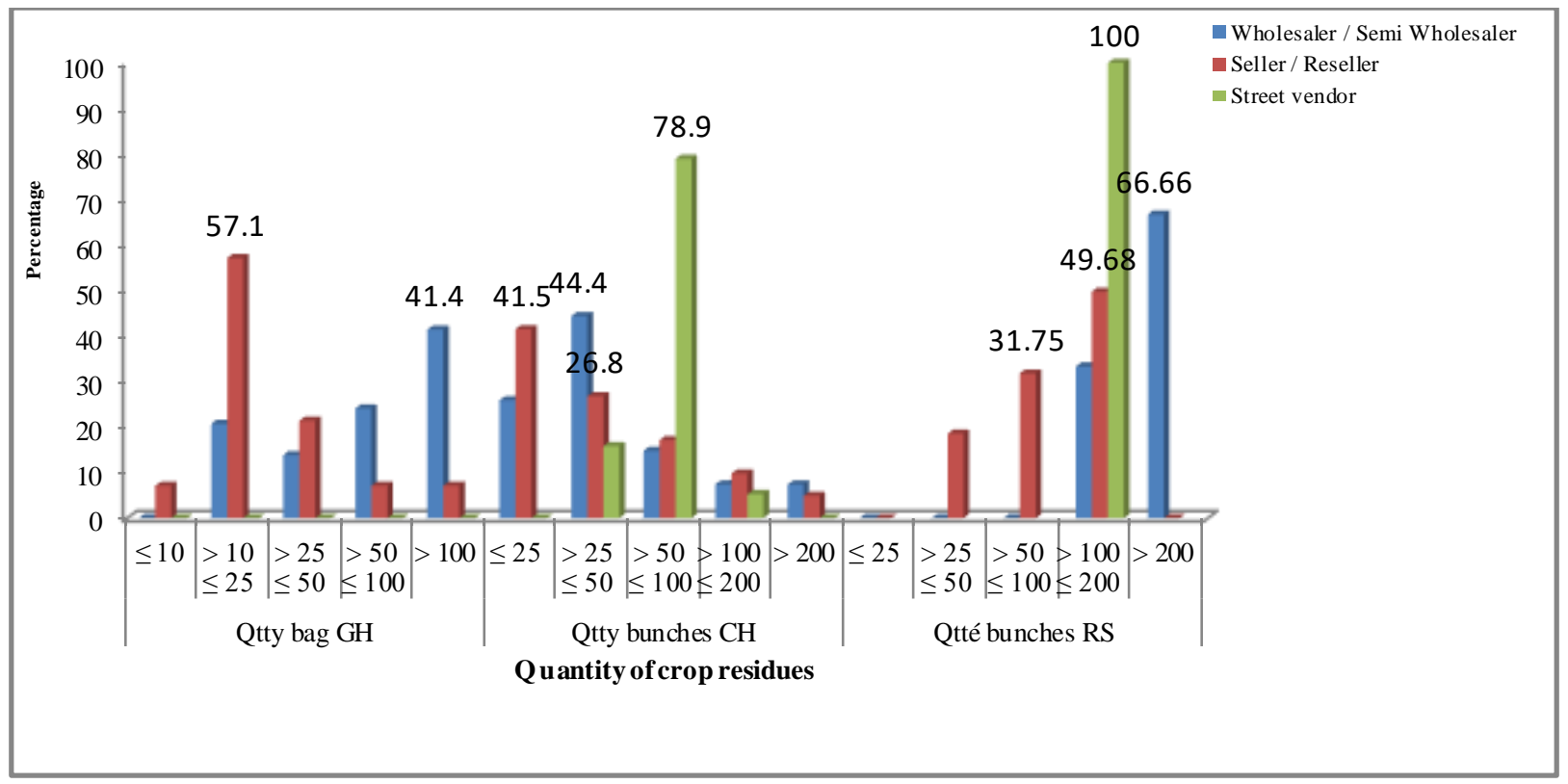

Fig. 4: Quantity of crop residues per supply

\subsubsection{Payment method of supply}

Overall, there are two modes of supply settlement: cash payment or cash and credit combination. This latter formula is the most widely practiced $(79 \%$ for wholesalers / semi-wholesalers, $61 \%$ for sellers / resellers and $74 \%$ for street vendors) (Figure 5). 


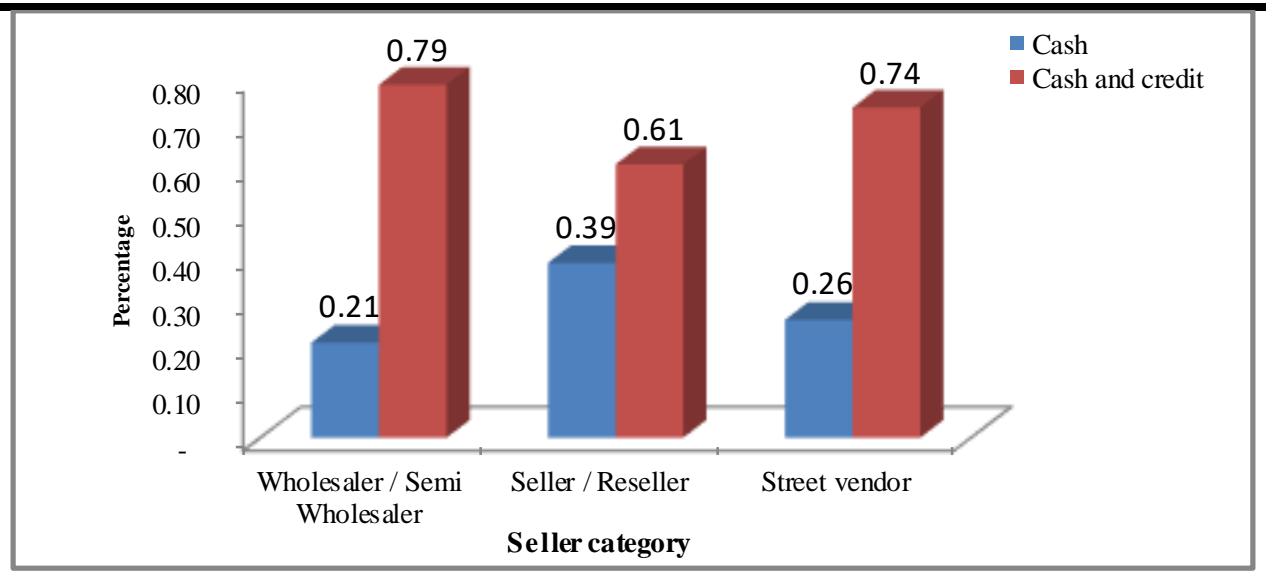

ISSN: 2456-1878

Fig. 5: Supply payments mode

\subsubsection{Storage}

The most common method is to store crop residues on bricks and / or tires and cover them with plastic (72.7\% wholesalers / semi-wholesalers and $87.5 \%$ resellers) (Figure 6).

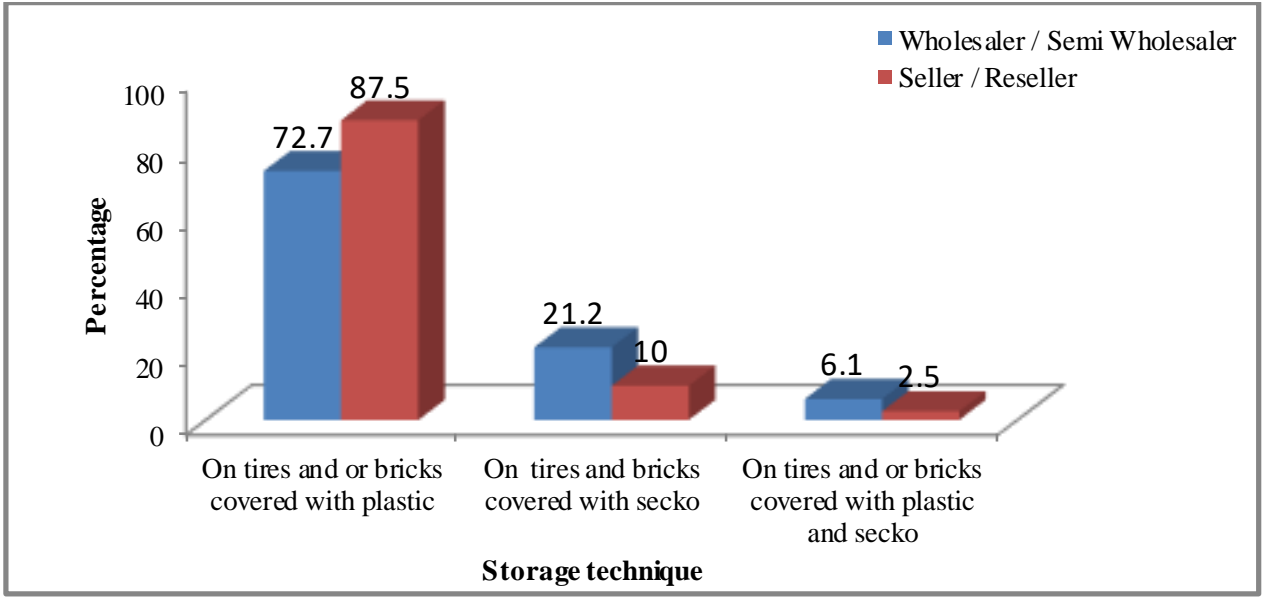

Fig. 6: Storage

Labor is used only by wholesalers / semi-wholesalers and sellers / resellers. Thus, $72.7 \%$ of wholesalers / semiwholesalers and $46.3 \%$ of sellers / resellers claim to use labor. It is mainly family-based $(91.7 \%$ for wholesalers / semi-wholesalers and $100 \%$ for sellers / resellers). In most cases this labor is used during all the periods of the year. The majority of wholesalers / semi-wholesalers $(87.9 \%)$ and sellers / resellers $(68.3 \%)$ pay a tax for the exercise of the crop residue marketing activity. It is mainly the installation tax for the town hall or the synthetic patent. It should be noted that street vendors are exempt from these (Table 3).

\subsubsection{Daily recipe}

Daily revenues are higher at wholesalers / semiwholesalers, mainly in the cold dry season (59803.03 \pm 60381.979FCFA). They are generally lower among sellers / resellers, especially during the rainy season (Table 4).

Table.2: Use of labor

\begin{tabular}{|c|c|c|c|c|c|c|c|c|}
\hline \multirow[t]{2}{*}{ Variable } & \multirow[t]{2}{*}{ Modality } & \multicolumn{2}{|c|}{$\begin{array}{l}\text { Wholesaler / semi } \\
\text { wholesaler }\end{array}$} & \multicolumn{2}{|c|}{$\begin{array}{l}\text { Seller/ } \\
\text { res eller }\end{array}$} & \multicolumn{2}{|c|}{ Street vendor } & \multirow[t]{2}{*}{$\mathrm{P}$ value } \\
\hline & & $\mathrm{N}$ & $\%$ & $\mathrm{~N}$ & $\%$ & $\mathrm{~N}$ & $\%$ & \\
\hline \multirow{3}{*}{ Use of labor } & Yes & 24 & 72.7 & 19 & 46.3 & - & - & \multirow{3}{*}{$* * *$} \\
\hline & No & 9 & 27.3 & 22 & 53.7 & 19 & 100 & \\
\hline & Total & 33 & 100 & 41 & 100 & 19 & 100 & \\
\hline \multirow{4}{*}{$\begin{array}{l}\text { Period of use of the } \\
\text { labor }\end{array}$} & Cold dry season & 1 & 4.2 & - & - & - & - & \multirow{4}{*}{ Ns } \\
\hline & Hot dry season & - & - & 1 & 5.3 & - & - & \\
\hline & All the dry season & 9 & 37.5 & 6 & 31.6 & - & - & \\
\hline & $\begin{array}{l}\text { Dry and rainy } \\
\text { season }\end{array}$ & 14 & 58.3 & 12 & 63.2 & - & - & \\
\hline
\end{tabular}




\begin{tabular}{|c|c|c|c|c|c|c|c|c|}
\hline & Total & 24 & 100 & 19 & 100 & - & - & \\
\hline \multirow{3}{*}{ Type of labor used } & domestic & 22 & 91.7 & 19 & 100 & - & - & \multirow{3}{*}{ Ns } \\
\hline & wage & 2 & 8.3 & - & - & - & - & \\
\hline & Total & 24 & 100 & 19 & 100 & - & - & \\
\hline
\end{tabular}

Table.3: Tax Payment

\begin{tabular}{|c|c|c|c|c|c|c|c|c|}
\hline \multirow[t]{2}{*}{ Variable } & \multirow[t]{2}{*}{ Modality } & \multicolumn{2}{|c|}{$\begin{array}{c}\text { Wholesaler/ semi } \\
\text { wholesaler }\end{array}$} & \multicolumn{2}{|c|}{ Seller/ reseller } & \multicolumn{2}{|c|}{ Street vendor } & \multirow[t]{2}{*}{$\mathrm{P}$ value } \\
\hline & & $\mathrm{N}$ & $\%$ & $\mathrm{~N}$ & $\%$ & $\mathrm{~N}$ & $\%$ & \\
\hline \multirow{3}{*}{ Tax payment } & Yes & 29 & 87.9 & 28 & 68.3 & 0 & 0 & \multirow{3}{*}{$* * *$} \\
\hline & No & 4 & 12.1 & 13 & 31.7 & 19 & 100 & \\
\hline & Total & 33 & 100 & 41 & 100 & 10 & 100 & \\
\hline \multirow{4}{*}{ Type of tax } & Town hall & 14 & 48.3 & 20 & 71.4 & 0 & 0 & \multirow{4}{*}{ Ns } \\
\hline & patent & 1 & 3.4 & 2 & 7.1 & 0 & 0 & \\
\hline & Mayor and patent & 14 & 48.3 & 6 & 21.4 & 0 & 0 & \\
\hline & Total & 29 & 100 & 28 & 100 & 0 & 0 & \\
\hline
\end{tabular}

Ns = not significant; $* * *=\mathrm{p}<0.001 ; \mathrm{N}=$ effective; $\%=$ Percent

Table 4: Daily recipe according to the seasons

\begin{tabular}{|c|c|c|c|c|c|c|c|}
\hline \multirow{3}{*}{ Actor category } & \multicolumn{7}{|c|}{ Daily recipe } \\
\hline & \multicolumn{2}{|r|}{ Rainy Season } & \multicolumn{2}{|r|}{ Cold Dry Season } & \multicolumn{2}{|r|}{ Hot Dry Season } & \multirow{2}{*}{$P$ value } \\
\hline & $\overline{\mathrm{N}}$ & Mean & $\mathrm{N}$ & Mean & $\mathrm{N}$ & Mean & \\
\hline $\begin{array}{l}\text { Wholesaler / Semi } \\
\text { wholesaler }\end{array}$ & 28 & $36767.86 \pm 35341.06$ & 33 & $59803.03 \pm 60381.98$ & 32 & $\begin{array}{l}53421.88 \pm 64048.1 \\
6\end{array}$ & \\
\hline Seller / Reseller & 21 & $13433.33 \pm 16510.1$ & 41 & $15136.59 \pm 19767.21$ & 26 & $\begin{array}{l}19119.23 \pm 23664.3 \\
5\end{array}$ & $* * *$ \\
\hline Street vendor & 9 & $28888.89 \pm 9279.61$ & 19 & $21171.05 \pm 9410.42$ & 13 & $21173.08 \pm 9323.68$ & \\
\hline Total & 58 & $27096.55 \pm 28540.99$ & 93 & $32218.82 \pm 43399.99$ & 71 & $\begin{array}{l}34955.63 \pm 48123.7 \\
3\end{array}$ & \\
\hline
\end{tabular}

*** $=\mathrm{p}<0.001 ; \mathrm{N}=$ effective

\subsection{Determinants of margins by type of actors}

The expenses related to the marketing of crop residues are mainly the costs related to refueling, packaging and storage; to labor and to the payment of tax. According to this study, in Niamey, the daily gross margin of a wholesaler / semi-wholesaler of crop residues is 14753.03 \pm 25724 .24FCFA. It is higher than that of street vendors $(6946.05 \pm 2204.23$ FCFA), which is also higher than that of resale sellers (5855.54 \pm 5065.49 FCFA) (Table 5).

Table 5: Daily gross margin by types of actors

\begin{tabular}{llcc}
\hline \multirow{2}{*}{ Topics } & \multicolumn{3}{c}{ Categories of actors } \\
\cline { 2 - 4 } & \multicolumn{1}{c}{ Wholesaler/ semi wholesaler } & Seller/ reseller & Street vendor \\
\cline { 2 - 4 } & & Mean & Mean \\
\hline Loads (FCFA) & $34802.31 \pm 29391.62$ & $9175.96 \pm 14633.72$ & $15332.08 \pm 7112.04$ \\
Feeding in fodder & $571.97 \pm 286.27$ & $676.83 \pm 328.05$ & $587.72 \pm 358.94$ \\
Labor & $357.14 \pm 303.05$ & - & - \\
Tax & $187.59 \pm 47.37$ & $198.49 \pm 173.6$ & - \\
Total expenses & $35919.01 \pm 30028.3$ & $10051.28 \pm 15135.37$ & $15919.8 \pm 7470.98$ \\
Products (FCFA) & & & $22865.85 \pm 9675.21$ \\
Daily recipe & $50672.04 \pm 55752.55$ & $15906.82 \pm 20200.86$ & $6946.05 \pm 2204.23$ \\
Gross margin & $14753.03 \pm 25724.24$ & $5855.54 \pm 5065.49$ & \\
\hline
\end{tabular}




\section{DISCUSSION}

\subsection{Socio-economic characteristics of the actors}

The marketing of crop residues is more an activity of male actors, whose age is between 40 and 60 years (Oumarou, 2016). This is apparent from this study, or only about $40 \%$ of wholesalers / semi-wholesalers are under 40 years of age. Compared with sellers / resellers (with almost 10\%) and street vendors (with nearly 30\%) of young people under 40 , this proportion represents the category of actors with the youngest people. The sellers / resellers were former street vendors of bush hay. They are of Zarma ethnicity and after getting older, settle down in strategic fixed places in search of potential customers (Lawal, 2014). The street vendors, for their part, are rural, single, of Fulani ethnicity for the most part. This is justified on the one hand, by the fact that the surrounding villages of the city of Niamey are mainly made up of Fulani, on the other hand, by the precariousness which reigns in the rural world making the conditions of life difficult in these environments. In wholesalers / semiwholesalers, it is rather actors of Hausa ethnic group, with a relatively young fringe. This situation can be explained by the fact that it is a profitable activity on the one hand (Maimouna, 2012), and on the other hand, by its ethnolinguistic character (Ouseseini et al, 2017) through the marketing of groundnut haulm. As a result, a large proportion of these $(60.6 \%)$ make the marketing of livestock feeds, their main activity. Although the marketing of fodder is a profitable activity for the actors (Aboh, 1999, Kiema et al, 2012, Sanou et al, 2011, Sanou et al, 2016), several reasons lead to the practice of commercialization of crop residues. This is inheritance and profitability, respectively for wholesalers / semiwholesalers $(30.3 \%$ and $24.2 \%)$ and street vendors (26.3\% and $31.6 \%)$. Among sellers / resellers, it is rather the survival $(24.4 \%)$, the passion $(22 \%)$ and the constraint (22\%) which constitutes the fundamental reasons for the practice of the activity. Usually, the sale of fodder is an activity of actors of ethnic Zarma (Ouseseini et al, 2017) from the Zarmaganda. Young people are engaged in street vending on carts and camels, and older sellers, usually over 40, settle into fixed places and are handed over by young people. Those with significant capital maintain relationships that allow them to be delivered in large quantities and become wholesalers / semi-wholesalers. The others who do not have substantial means remain sellers / resellers by constraint because their survival depends on it. Nevertheless, a large group of wholesalers / wholesalers and street vendors have engaged in this fodder business because it generates a lot of revenue (Maimouna 2012, Dan Gomma et al, 2017). Sellers / resellers are usually sourced locally at the point of sale, usually by street vendors or a few wholesalers / semiwholesalers. Although this situation exempts shipping and handling costs from the products, it significantly reduces the margin of the sellers / resellers' customer base, because of having products with a relatively high price.

\subsection{Marketing and supply management}

The different types of crop residues used as livestock feed, encountered in the marketing channel, are cowpea, groundnut and rice straw. In Bobo Djioulasso in Burkina Faso, it is rather stalks of millet, sorghum and corn instead of rice straw (Sanou, 2016). These last are object of specific sale, or of combined sale at the level of the various actors. In fact, all the street vendors surveyed sell cowpea hay and $36.84 \%$ of them sell the rice straw and more. This situation is explained by the fact that the production of groundnuts in the urban community of Niamey and its surroundings is almost non-existent. The banks of the Niger River are valued mainly by growing rice through two productions per year (Siddo 2010, Gergely 2014, Dan Gomma et al 2017). Cowpea is generally associated with cereals (millet and sorghum). Cereal stalks are not found in the marketing market at the level of the different actors because they are either used by the producer himself for feeding his animals and other uses such as fences, or sold directly to breeders (Dan Gomma et al, 2017). The quantity and nature of crop residues by supply depends on the category of actor (Sanou et al, 2011). Street vendors are more interested in cowpea haulm and rice straw boots. Supply quantities are in most cases between 50 and 100 boots of cowpea hay (78.9\%) and 100 and 200 boots of rice straw (100\%). These quantities generally represent the carrying capacity of the carts. The amount of cowpea haulm is relatively inferior to that of rice straw because the packing of cowpea haulm does not allow them to be compacted in order to better preserve the leaves, while the rice straw can. It should also be noted that rice straw has a lower nutritional value, with a price that is relatively low. Therefore, to make the trip profitable, you need a relatively large load. As for wholesalers / semiwholesalers, the importance of supply is mainly in groundnut and rice straw fodder, with quantities per supply generally greater than 100 boots of groundnut fane $(41.4 \%)$ and 200 boots of rice straw $(66.66 \%)$. Groundnut leaves come from the interior of the country mainly from the Maradi and Tahoua region (Niger, 2015c) and rice straw from the riverbanks at the producer level (Dan Gomma et al, 2017). Wholesalers / semi-wholesalers acquire it per production plot and carry it on carts. Sometimes street vendors serve as carriers for this task. These quantities of groundnuts and rice straw are most often used to supply sellers / retailers who obtain small quantities because they have small means, but also to feed the herdsmen through a small part used to feeding the stand of the wholesaler / semi-wholesaler in person. The method of payment of the cash supply is very rare. Cash 
and credit are the most common methods of payment (79\% for wholesalers / wholesalers, 61\% for sellers / resellers and $74 \%$ for street vendors). This allows those who cannot afford cash to have the products on credit for a small advance. The rest of the money will be paid in full at the next delivery. This observation is similar to that made by Oumarou (2016).

The subsequent storage and storage of crop residues is done on old tires and / or bricks. They are then covered by tarpaulins or polystyrene plastic (Lawal, 2014, Oumarou, 2016, Ousseini et al, 2017) or secko. Tarpaulins are used for their thickness, hardness and weather ability whereas polystyrene plastics are used for their easy handling and relatively low cost. The seckos, on the other hand, are those resulting from slump, which are at the beginning of degradation or completely degraded. In this way, the cost of storage and storage is reduced.

In this crop residue marketing activity, a significant number of wholesalers / semi-wholesalers (72.7\%) and sellers / resellers (46.3\%) use labor. This workforce, mainly family consists of members of the family of the actor. Sometimes they are schoolchildren who serve as labor during the off-class periods. This workforce is unpaid because it is an integral part of the family. However, in case of marriage or baptism and or religious festival, the expenses of the latter are the responsibility of the actor. Through this study, $(87.9 \%)$ wholesalers / semiwholesalers and $(68.3 \%)$ sellers / resellers claim to pay taxes for the town hall.

It is mainly the installation tax and the synthetic patent. It should be noted that these settle without prior authorization from the municipality. For this purpose, they are subject to recurrent displacement for lack of permanent place. Thus, for the maintenance and preservation of their place, they are confronted with a system of racketing by the collection agents of the municipality. This is one of the main constraints linked to the marketing of fodder in general (Lawal 2014, Soule 2014).

\subsection{Determinants of margins by type of actors}

The proper conduct of the crop residue marketing activity requires costs related to refueling, packaging, storage, labor and the payment of taxes and duties. Daily revenues are higher at wholesalers / semi-wholesalers, mainly in the cold dry season (59803.03 \pm 60381.979 FCFA). It is lower among sellers / resellers during the rainy season. In fact, the variations and fluctuations in the price of fodder for general stoves depend on the season, the type of fodder and the type of packaging (Manzo 2009, Soulé 2014, Oumarou 2016, Dan Gomma et al 2017). According to Sadoud (2010), feed prices depend mainly on the periods and behavior of the storers. This activity generates a daily gross margin of $14753.03 \pm$ 25724.24FCFA at a wholesaler / semi-wholesaler. It is higher than that of street vendors (6946.05 \pm 2204.23FCFA), which is also higher than that of resale sellers (5855.54 \pm 5065.49 FCFA). The quantity of the product and its availability play a very important role in the realization of profit.

\section{CONCLUSION}

It follows from this study that the marketing of crop residues in the urban community of Niamey is an activity reserved mainly for male actors, whose age is between 40 and 60 years. The main reasons that lead to this activity are legacy and profitability, survival, passion and coercion. The quantity and nature of crop residues by supply is a function of the category of actor and the method of payment of cash supply is very rare. The storage of products is done on old tires and or bricks, covered by tarpaulins or polystyrene plastics. The labor used is mainly family and consists of members of the actor's family. It also shows that the marketing of crop residues is a very profitable activity for the actors, especially in the cold dry season. However, the recurrent displacements of the actors for lack of fixed place coupled with the harassment of the agents of recovery of the municipalities represent a brake with the development of this activity. It would therefore be imperative to regulate their implementation while facilitating the procedures leading to the granting of installation authorizations.

\section{ACKNOWLEDGMENTS}

The authors thank the West Africa Agricultural Productivity Program (WAAPP-Niger) for funding this work.

\section{REFERENCES}

[1] Aboh BA, 1999. La commercialisation de fourrages verts au marché de Zongo à Cotonou : état des lieux et contraintes. Bulletin. Recherches. Agronomiques. 25 , 8 $\mathrm{p}$. http://www.slire.net/download/1170/aboh bra 025 1999. pdf.

[2] Beidari S, 1999. Bilan et perspectives de la production laitière en zone périurbaine au Niger: cas de la Commune Urbaine de Niamey. IPR/IFRA: Bamako. 120 p.

[3] Chaibou M, Yaou OM, Gouro A, Laouali A, 2012. Diversité, disponibilité et circuits d'approvisionnement des aliments du bétail dans la communauté urbaine de Maradi. Journal des Sciences de l'Environnement 1 (1) : 27-34.

[4] Dan Gomma A, Chaibou I, Banoin M et Schlecht E, 2017. Commercialisation et valeur nutritive des fourrages dans les centres urbains au Niger: cas des villes de Maradi et de Niamey. International Journal of Innovation and Applied Studies, 21, 3, 508-521. 
[5] Faye B, et Alary V, 2001. Les enjeux des productions animales dans les pays du sud. INRA Productions Animales. 14 (1), 3-13.

[6] Gergely N, 2014. Note d'analyse sur la filière riz au Niger. Banque mondiale-Niamey, 30p.

[7] Kiema A, Sawadogo I, Ouédraogo T et Nianogo AJ, 2012. Stratégies d'exploitation du fourrage par les éleveurs de la zone sahélienne du Burkina Faso. Int. J. Biol. Chem. Sci. 6(4): 1492-1505. DOI : http://dx.doi.org/10.4314/ijbcs.v6i4.8

[8] Lawal MA. 2014. Aspects socioéconomiques de l'utilisation des résidus de cultures et des Sous produits agroindustriels dans l'alimentation des ruminants domestiques à Niamey (Niger). Mémoire de Master, Ecole Inter-états de Sciences et Médecine Vétérinaire (EISMV)- Dakar-Sénégal. 43p.

[9] Maidadji B, 2003. L'élevage au Niger: systèmes en place, politiques commerciales, atouts et limites. In: Ehui S., Barry M.B., Williams T.O., Koffi K.M., Zeleka P. (eds). Quelles politiques pour améliorer la compétitivité des petits éleveurs dans le corridor central de l'Afrique de l'ouest: implications pour le commerce et l'intégration régionale. Proceedings of a workshop held in Abidjan, Côte d'Ivoire, 17-18 September 2001. ILRI (Institut international de recherche sur l'élevage), Nairobi, Kenya.-88 p.

[10] Maimouna D, 2012. Contribution des fanes de niébé (Vigna unguiculata) dans l'alimentation du bétail dans la ville de Niamey ; Mémoire Master 2 Faculté d'Agronomie/UAM, 54p/

[11] Manzo Rio-Rio A, 2009. Étude du flux de fourrage vert des zones périurbaines vers la ville de Niamey en saison pluvieuse. Mémoire de master ès sciences Agronomiques, UAM, Faculté d'Agronomie 44p.

[12] Niger, 2015a. Annuaire statistique régional 2010 2014. Institut national de la statistique : Niamey.

[13] Niger, 2015b. Synthèse des résultats de la campagne pastorale 2015-2016: Version provisoire. Ministère de l'élevage : Niamey.

[14] Niger, 2015c. Rapport de mission de capitalisation des expériences de production et valorisation des fourrages dans les régions de Dosso, Tahoua, Agadez et Maradi. Direction générale des productions et industries animales. Ministère de l'élevage : Niamey.

[15] Niger, 2016. Recensement général de la population et de l'habitat 2012. Institut national de la statistique : Niamey.

[16] Oumarou H, 2016. Etude de la filière des fanes de légumineuses utilisées dans l'alimentation du bétail : Cas des élevages de la Communauté Urbaine de Niamey (Niger). Mémoire de Master, Ecole Interétats de Sciences et Médecine Vétérinaire (EISMV)Dakar-Sénégal. 41p.
[17] Ousseini MMM, Chaibou M, Mani M, 2017. Pratique et utilisation des sous-produits de légumineuse dans l'alimentation du bétail à la communauté urbaine de Niamey : Cas de fanes et cosses de niébé (Vigna unguiculata). Journal of Applied Biosciences, 120: 12006-12017. https://dx.doi.org/10.4314/jab.v120i1.3

[18] Rhissa Z. 2010. Revue du secteur de l'élevage au Niger. Rapport provisoire. FAO/SFW : Niamey.

[19] Sadoud M. 2010. Rôle des marches du bétail, dans les filières viandes bohaulm et ohaulm d'une région semi-aride Algérienne département d'Agronomie HLEF (02000). Revue scientifique, Université $H$. Benbouali, in International EAAE-SYAL, Seminar Spatial Dynamics in Agri-Food Systems ; 7.

[20] Sanou KF, Nacro S, Ouédraogo M, Ouédraogo S et Kaboré-Zoungrana C. 2011. La commercialisation de fourrages en zone urbaine de Bobo-Dioulasso (Burkina Faso) : pratiques marchandes et rentabilité économique. Cah. Agric. 20(6): 487-493. DOI:10.1684/ agr.2011.0530.

[21] Sanou KF, Ouédraogo S, Nacro S, Ouédraogo M et Kaboré-Zoungrana C. 2016. Durabilité de l'offre et valeur nutritive des fourrages commercialisés en zone urbaine de Bobo-Dioulasso, Burkina Faso. Cah. Agric. 25: $15002 . \quad$ DOI: 10.1051/cagri/2016007.

[22] Sido YA, 2010. Etat des lieux de la riziculture : Cas du Niger. FAO-Niamey. 57p.

[23] Soulé M, 2014. Analyse du système de commercialisation du fourrage dans la ville de Niamey (Niger). Mémoire de Master, 'Ecole Interétats de Sciences et Médecine Vétérinaire (EISMV)Dakar-Sénégal. 28p.

[24] Steinfeld H, Mooney HA, Scheider F, Neville LE. 2010. Livestock in a changing landscape: (Volume 1). Drivers, Consequences and Responses. Island Press: Washington.

[25] Zoffoun AG, Aboh AB, Adjolohoun S, Houinato M, Sinsin B. 2013. Effet de l'âge et de l'intensité de pâture sur le développement des touffes et la production de biomasse de Panicum maximum var. $\mathrm{C} 1$ dans les pâturages artificiels en zone soudanienne et subéquatoriale. Int. J. Biol. Chem. $\begin{array}{llll}\text { Sci., } & \mathbf{7}(3) \text { : } & 1168-1179 . & \text { DOI: }\end{array}$ http://dx.doi.org/10.4314/ijbcs.v7i3.23. 